\title{
Mourning and Takotsubo cardiomyopathy: neuroendocrine implications and nutritional management
}

\author{
Maria Teresa Fialho de Sousa Campos ${ }^{1}$ \\ Francisco Miguel Quintão Valente ${ }^{2}$ \\ Raquel Maria Amaral Araújo ${ }^{3}$ \\ (iD) Josefina Bressan ${ }^{4}$
}

\begin{abstract}
1. Assistant Professor. Department of Nutrition and Health - DNS, Federal University of Viçosa (UFV), campus Viçosa, Viçosa (MG), Brasil. 2. Cardiologist. Clínica do Coração - Clinicor e Serviço de Cardiologia do Hospital São Sebastião, Viçosa (MG), Brasil. 3. Associated Professor. Department of Nutrition and Health - DNS, Federal University of Viçosa (UFV), campus Viçosa, Viçosa (MG), Brasil. 4. Senior Professor. Department of Nutrition and Health/UFV. Post-Graduation Program of Nutrition Sciences, Federal University of Viçosa, Viçosa (MG), Brasil.
\end{abstract}

\section{SUMMARY}

This article aims to make reference to some recent mourning aspects considered risk factors for cardiovascular disease, specifically the Takotsubo cardiomyopathy. The objective was to describe the stress from the death of a loved one combining it to the possibility of occurrence of Takotsubo cardiomyopathy through the perception of a traumatic event by the cortex, which triggers the subcortical brain circuit affecting the endocrine response. Given the growing acknowledgement of this cardiomyopathy, it is possible to contextualize the nutritional behaviours and decisions surrounding it, whose benefits must exceed the condition of temporary cardiac dysfunction and extend to food choices that have some influence in the limbic system. It is a descriptive analysis that aims to problematize the theme into reflections based on this experience, considering the foundation with the science of nutrition.

KEYWORDS: Takotsubo cardiomyopathy. Bereavement. Death. Nutritional Support.

\section{INTRODUCTION}

Faced with death, the constancy of intense affective-emotional reactions is what classifies the event as a traumatic stressor ${ }^{1}$. The difficulty in coping with the death of a loved one favours the intensity and duration of reactions mediated by biophysiological and psychological mechanisms that may be more devastating to the organism ${ }^{2}$, allowing the manifestation of Takotsubo cardiomyopathy (TC).

Although the pathophysiological mechanisms of TC are not fully understood, ${ }^{3}$ its association with high stress has focused attention on the autonomic nervous system ${ }^{4}$, whose evidence suggests that it is a reflex response controlled by this system ${ }^{5}$ - since patients with Takotsubo have higher levels of catechol- amine than those with acute myocardial infarction ${ }^{6}$; endomyocardial biopsy is typical of this elevation ${ }^{7}$; and myocardial dysfunction induced by increased catecholamine is the most likely mechanism for $\mathrm{TC}^{8}$.

Because of this, the exacerbated response of catecholamine is pointed out as a central factor for the occurrence of this cardiomyopathy ${ }^{5,7,9}$. In this follow-up, consideration is given to the organic effects to the myocardium in line with the impact of death of a loved one, which has implications on hormonal mediators. Based on this premise, it was important to discuss the effects of recent mourning on the cardiovascular system from the perspective of Takotsubo cardiomyopathy and its repercussion on nutri- 
tional management, based on the neuroendocrine implications associated with the trauma of losing a loved one. It should be noted that TC is referenced by other names ${ }^{5,8,10-15}$, among which the expression Broken Heart Syndrome $e^{5}$ is included in the scope of this article.

\section{METHODS}

A search for scientific articles with the topics of Takotsubo Cardiomyopathy and Mourning was carried out. The following descriptors were searched in the Capes journal portal and the Science Direct and SciELO databases: "Takotsubo syndrome"; "Takotsubo cardiomyopathy"; "broken-heart syndrome". Other sources of research were: "death" and "stress"; "mourning" and "neuroendocrine responses"; "effects of bereavement"; "bereaved parents"; "grieving process". Publications that did not meet the criteria of interest were excluded from the theoretical reference. The bibliographic research was conducted from May to August 2017, without period restriction, given the need for unified information to support this review. It is a descriptive analysis, based on the main heart alterations of the TC, contextualizing the broken heart syndrome in the face of mourning and nutritional management. To further substantiate this descriptive analysis, the content was organized into three sections: Takotsubo cardiomyopathy in mourning; Takotsubo cardiomyopathy from the perspective of the loss of a loved one; and nutritional management in Takotsubo cardiomyopathy.

\section{TAKOTSUBO CARDIOMYOPATHY IN MOURNING}

Depending on the particularities of each person, the emotional regulation profile ${ }^{16}$ and the affective bonds established between people, the death of a loved one can trigger a strong psychological emotion that can result in cardiac changes. Mourners look for emergency care ${ }^{17,18}$ especially for the fear of having a heart attack. Mourning can increase the risk of acute myocardial infarction (AMI) by up to 21 times, an assertion based on a sample of 1,985 patients, where the increased risk is noted within the first 24 hours after the death of the loved one ${ }^{19}$. As angiographic data were not available, the investigators ${ }^{19}$ claim that it cannot be ruled out the possibility that some cases refer to TC. Despite its rarity, an AMI may not ex- clude a cardiomyopathy of stress, and it could even be its trigger ${ }^{11}$. The TC precipitant commonly falls into the stressful physical or emotional condition ${ }^{14}$; however, the lack of a precedent does not exclude the diagnosis ${ }^{5}$.

Given that there is an association between mourning and loss experience with heart disease, ${ }^{20}$ and that in the first few days, weeks and months after the death of a loved one, cardiovascular disease represents an increase in the risk of death during mourning ${ }^{19}$, subtle differences between heart attack and TC deserve appreciation, as the symptoms are similar ${ }^{6}$. In TC, coronary cineangiography does not show significant obstructions ${ }^{10}$ - indicating that the primary cause is not related to obstructive coronary disease $^{9,21}$ and ventriculography reveals apical ballooning of the left ventricle due to akinesia, with basal hyperkinesia similar to dumbbells or Takotsubo ${ }^{6}$ - characteristic image of the syndrome ${ }^{10}$ (Figure 1).

FIGURE 1: VENTRICULOGRAPHY SHOWING THE DIASTOLE (1) AND SYSTOLE (2) OF TAKOTSUBO'S CARDIOMYOPATHY. (LEFT VENTRICLE IN SYSTOLE, WITH THE CLASSIC IMAGE OF THE SYNDROME THAT RESEMBLES THE JAPANESE TAKOTSUBO POT)

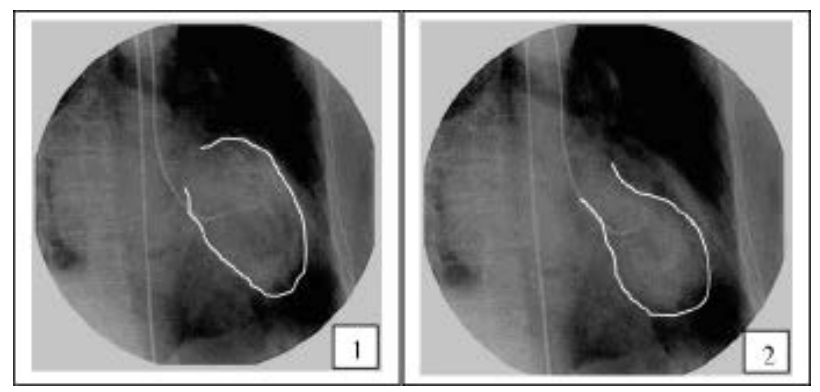

In the TC electrocardiogram (ECG) pattern, a greater number of derivations with ST segment horizontal depression in the inferior wall $1^{3}$ and/or $\mathrm{T}$ wave inversion ${ }^{14,22}$ are identified, with a prolonged QT interval ${ }^{23}$, although there are differences in this pattern $^{24,25}$ and the ECG may not be specific ${ }^{14}$. Laboratory tests reveal a slight elevation in the serum concentration of markers of myocardial injury ${ }^{6,10,12}$ disproportionate to the area affected to the $\mathrm{ECG}^{8,23}$. Levels of B-type natriuretic peptides, which reflect left ventricular systolic dysfunction, are elevated ${ }^{8}$, with values higher than those found in $\mathrm{AMI}^{14,26}$. Although the term stunned cardiac muscle is used to indicate cardiac injury in Takotsubo ${ }^{4}$, the lack of elevation of the enzymes does not exclude the diagno$\operatorname{sis}^{5,26}$.

Other biomarkers have been reported ${ }^{27,28}$. The 
alpha tumour necrosis factor (TNF- $\alpha$ ) and the soluble form of its receptors (sTNFR-1 and sTNFR-2) are involved in myocardial dysfunction ${ }^{27-29}$, although its effects may include adaptive responses to cardiac protection $^{29}$. The increase of TNF- $\alpha$ is influenced by the plasma concentrations of catecholamines ${ }^{30}$; in response to its stimulus, other proinflammatory cytokines are released, whose activation occurs early to cardiac alterations ${ }^{27}$. Despite the clinical importance of cardiac biomarkers, in post-traumatic stress conditions, their dosages should compose routine exams.

Among the care given to the mourners, which need to start early on, attention must be given to the cardiac conditions of these individuals. Greater attention to the established diagnostic criteria ${ }^{25}$ in guidelines ${ }^{23,31}$ for TC, aligned with the mourning, can provide the actual dimension of this association.

The literature has presented clinical cases that associate TC with mourning ${ }^{32}$. A possible link between cognitive emotional processing and vulnerability to Takotsubo syndrome was evidenced in a clinical case, after a domestic discussion, with a history of death of a loved one, six months before the symptoms ${ }^{32}$. For Redfors et al..$^{33}$, psychiatric conditions may predispose an individual to develop stress-induced cardiomyopathy in response to a strong stressor. Due to other evidences ${ }^{34,35}$, a deeper understanding of this phenomenon imposes investigations on the interface: post-traumatic stress due to death of a loved one and biological predisposition to TC.

\section{TAKOTSUBO CARDIOMYOPATHY FROM THE PERSPECTIVE OF THE LOSS OF A LOVED ONE}

According to Crawford and Schaffer ${ }^{36}$, the healthy heart has signalling mechanisms through which it responds to metabolic stress with a remarkable degree of efficiency to meet the high demand and plasticity in response to changes, varying in the supply of the energy substrate to provide for homeostatic, mechanical and electrical activities. Dysfunction in contraction and damage appear when this capacity is exceeded ${ }^{36}$.

In an attempt to explain the pathogenesis of TC, several theories have been proposed. Although the pathophysiology is not fully elucidated, there is consensus about the action of catecholamines ${ }^{5,26,37}$. For Coupez et al. ${ }^{37}$, the common denominator in TC is catecholaminergic stress. High concentrations of catecholamine may cause damage to the myocardi$\mathrm{um}^{4}$ through the supraphysiological activation of $\beta 1$ and $\beta 2$ beta-adrenergic receptors, by activating adenylate cyclase by interacting with stimulatory $G$ protein, elevating the formation of intracellular cyclic adenosine monophosphate that activates protein kinase $\mathrm{A}$ - this phosphorylates membrane proteins, increasing the influx of calcium into cells and oxidative stress ${ }^{7}$. This would lead to disturbance of ventricular contraction and function, which may decrease the viability of cardiac myocytes ${ }^{26}$. The interaction of this mechanism with other individual predisposing factors may favour TC.

Among the factors that can trigger an overload of catecholamine in the body is the death of the loved one and the trauma that occurred during this event. The perception of a traumatic event by the cortex triggers the subcortical cerebral circuit, through the structures that control the emotions and the functions of the visceral systems, whose activation triggers the release of norepinephrine in the hypothalamus $^{2}$. Therefore, the release of epinephrine from the marrow of the adrenal gland is induced ${ }^{26}$. Dealing with the news of death and the loss of a loved one is an aggression of a psychogenic nature. In this circumstance, the fundamental hormonal element of organic reactive response is the corticotrophin releasing hormone ${ }^{38}$; in response, the pituitary gland releases the adrenocorticotrophic hormone (ACTH), which stimulates the secretion of corticosteroid hormones and catecholamine by the adrenal glands ${ }^{2}$. Catecholamine induce myocardial adrenergic stimulation; the excess release induces toxicity in cardiac myocytes because it causes a calcium overload in myocytes ${ }^{7}$, leading to alterations in cardiac contractility - a more accepted proposition for $\mathrm{TC}^{26}$ (Figure 2).

Hypercortisolemia is associated with $\mathrm{AMI}^{39}$ and other heart diseases ${ }^{40}$; it induces proteolysis and lipolysis' ; and may involve the increase of visceral fat that is associated with metabolic disorders ${ }^{41}$. The organic imbalance appears when the changes are repetitive, coming from an excessive activation, plausible condition of occurrence in the bereavement of children and partners of a lifetime, because, in the psychic complexity of these mourning, the expected hormonal compensatory response will not always occur $^{2}$. Not living with a child anymore (due to death) emotionally destabilizes parents - reactions and disorders arise as a direct consequence of stress or continuous trauma ${ }^{42}$, altering the endocrine response, 
FIGURE 2: VULNERABILITY TO TAKOTSUBO CARDIOMYOPATHY FROM THE PERSPECTIVE OF THE TRAUMA OF LOSING A LOVED ONE

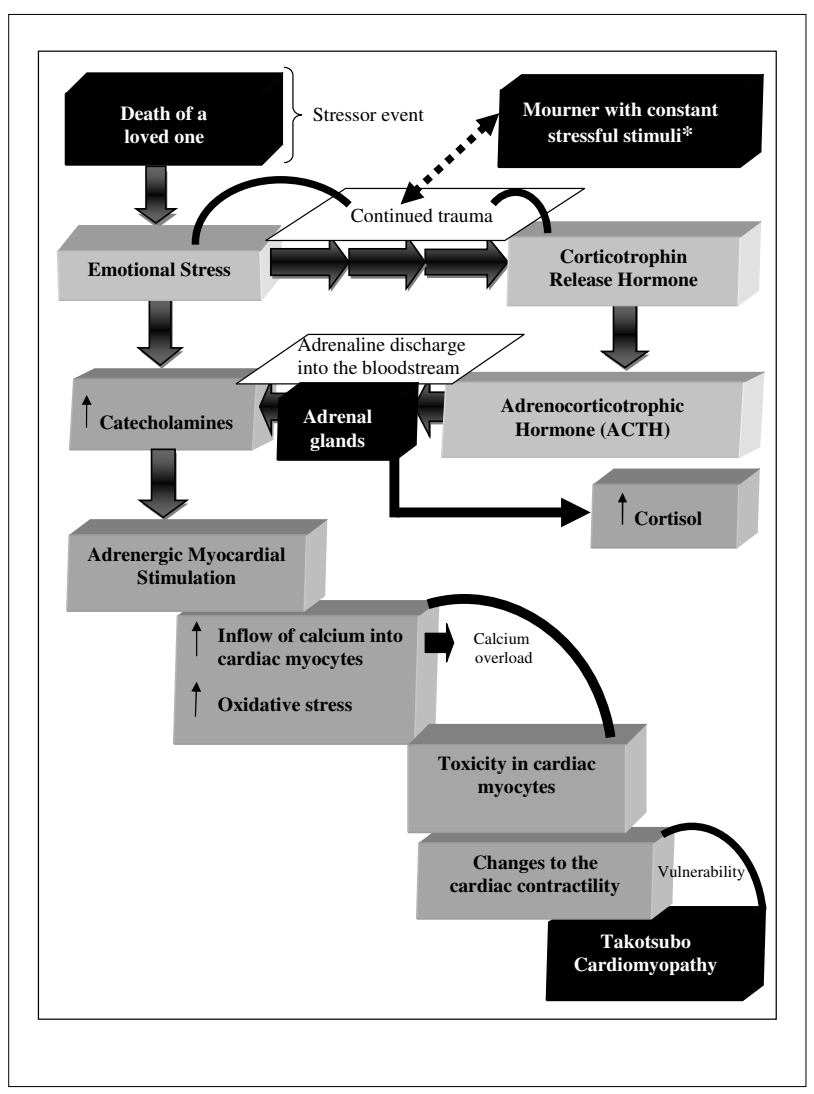

"Stressful stimuli coming from anguish, deep sadness and thought focused on the cause of death, on the loss of the loved one and the absence of the loved one.

which in turn has reflexes in other metabolic pathways, deserving more investigations since it portrays a differentiated issue of mourning in confrontations and adaptations. On the other hand, the loss of a daily present partner ${ }^{34}$, depending on affective attachment, emotional shock ${ }^{9}$ and cardiac conditions, may favour the occurrence of TC, especially at more advanced ages.

Effects of mourning state and grief time on cortisol response revealed a significant interaction, indicating differences in cortisol response pathways in mourners and non-mourners ${ }^{43}$. The increase of cortisol by psychological disorders in non-mourners is less expressive than in mourners. The interaction of the significant loss of the loved one with the grief time evidenced the persistence in the increase of this hormone, having differences in values, as a result of the death ${ }^{43}$. It may be hypothesized that, in the case of recent mourning, the vulnerability to TC lies in the abnormal activation of the hypothalamus-pituitary-adrenal axis with the constancy of in- tense affective-emotional reactions; and the cause of the death of the loved one is an aggravating factor, because it intensifies the psychic trauma - "feeding" the psychological distress, since it recalls strong and painful memories that constitute constant stressful stimuli. Under conditions of excessive sympathetic stimulation, one must also consider the possibility of reduced parasympathetic modulation, whose impaired control may play a relevant role in $\mathrm{TC}^{44}$.

\section{NUTRITIONAL MANAGEMENT IN TAKOTSUBO CARDIOMYOPATHY}

Initially, the goal is to alleviate cardiac overload by opting for the nutritional management that apply to this condition. Therefore, restriction of salt (sodium chloride) in cooking and of salt-based condiments, non-addition of salt in ready-made foods, restriction of industrialized foods with high sodium content in their composition and the control of water intake are crucial recommendations whose effects on the body must be carefully monitored. To give a pleasant flavour to the meal, preferably combine spices referenced with cardioprotective properties ${ }^{45,46}$ with aromatic herbs.

Due to myocardial injury, include food sources of phenolic compounds, which, depending on their absorption and metabolism, can modulate the expression of various biomarkers, attenuating oxidative stress and reducing proinflammatory cytokines ${ }^{47}$. As for fruits, preference should be given to those with purple and red colors ${ }^{48}$, citrus ${ }^{49}$ and oleaginous, ${ }^{50}$ because they contain a higher content of phenolic compounds. Calculate daily fructose intake to avoid that its excess can contribute to the increase of uric acid via degradation of adenosine monophosphate (AMP) from adenosine triphosphate (ATP) generated in the metabolism of fructose, which is converted into uric acid. Although uric acid is considered an important antioxidant in human plasma, supranormal levels in the blood have repercussions on cardiovascular function $^{51}$. Hyperuricemia inhibits the release of nitric oxide, which activates the renin-angiotensin system, constituting an important collaborator in determining cardiovascular risk ${ }^{52}$, and it also has an impact on the diagnosis of the metabolic syndrome ${ }^{53,54}$. Moderate fructose consumption, $\leq 50 /$ day, has no harmful effect on health ${ }^{55}$; excesses can exert harmful effects on metabolic analogies to ethanol, differing only by non-metabolization in the central nervous system ${ }^{56}$. 
However, due to TC, it is prudent that the ingested fructose is between 25 and $30 \mathrm{~g}$ daily. Consult the fructose content in fruit types to establish the quantities and size of the portions and avoid processed foods containing sucrose or fructose-rich corn syrup. In order to keep the serum concentration of uric acid in the normal range, also designate, in daily portions, foods with a more expressive content of purines - the main precursor of uric acid.

Ensuring homeostasis of the enteric microbiota is another behaviour known for its beneficial effects ${ }^{57-60}$. The combined use of pre-and probiotic foods has a hypolipidemic effect ${ }^{58}$ and is suggested to reduce plasma concentrations of toxins in plasma and, given the ability of bacteria to produce and recognize neurochemicals, it has been indicated as a therapeutic adjuvant for brain chemistry. ${ }^{59,60}$ The replacement of probiotics (through diet) is done with the daily intake of products such as fermented milk and kefir, and of prebiotics as ingredients in the culinary - field with increasing evidences in nutritional benefits. It is recommended to include pre and probiotic products duly regulated by the competent bodies of each country to recommend those with substantiated claims.

Balance amounts and types of fats (monounsaturated, polyunsaturated and saturated) provided by dietary intake, through analysis of tests that results in individual guidelines ${ }^{48}$ and restriction of trans fats ${ }^{61}$. Adequate consumption of polyunsaturated fatty acids contributes to a decrease in the hepatic production of VLDL (very low density lipoprotein) ${ }^{58}$, improvement in antiarrhythmic effects, among other benefits ${ }^{61}$. Up to $10 \%$ of the diet caloric value of polyunsaturated fat diet $^{62}$ is recommended in combination with foods that contain antioxidants ${ }^{48}$ - excessive intake may lead to increased lipid oxidation, decreasing HDL-c (high density lipoprotein cholesterol $)^{58}$. Polyunsaturated fats, when exposed to heat and oxygen, favour processes of oxidation and other chemical changes. Culinary methods that use high temperatures and low humidity (frying, roasting or grilling) potentiate the formation of advanced glycation products (AGEs), ${ }^{63}$ which, in excess, favour injuries to the tissues, predisposing the organism to the progression of diseases, including cardiovascular diseases, causing oxidative stress and increasing the expression of inflammatory mediators ${ }^{64}$. Gentle preparation methods with high water activity generate lower levels of these compounds ${ }^{65}$ and restrict cooking fats ${ }^{66}$. Although the formation of AGEs is predominantly endogenous in the body, they can be introduced by exogenous sources ${ }^{63}$ especially incorporated in foods ${ }^{64}$. The diet to attenuate myocardial injury should add to the dietary recommendations for fats and cardiovascular health ${ }^{61}$ the control of dietary AGEs intake, in order not to exceed the body's capacity to degrade these compounds, benefiting recovery.

If there is heart failure and volume overload, the use of diuretics is administered ${ }^{14,21,26}$; in these cases, ensure the presence of food sources of potassium in the composition of the meals, coupled with adequate monitoring in the organic response to avoid other electrolyte disturbances.

In view of the reestablishment of cardiac functions, the conducts inherent to the limbic system must be instituted. The limbic system is a complex combination of various structures of the brain that receives sensory stimulation, which is translated into emotional and psychological expression, regulating various functions in the organism ${ }^{67}$. If the balance in the chemistry of this system interferes with emotional health, the contribution of precursors of neurotransmitters responsible for the feelings of well-being must be restored through $\operatorname{diet}^{48}$. When the person suffers a significant loss, such as the death of a child, the sadness can be intense and prolonged, characterizing a condition of mental depression or of adjustment disorder ${ }^{2}$. A balanced supply of these chemical transmitters is essential so that the body can respond better to the stressor event. For example, to benefit serotonin production, consider food sources of tryptophan in balance with carbohydrates (aiming to increase the uptake of tryptophan in the cerebrospinal fluid in competition for the transporter that crosses the blood-brain barrier) ${ }^{48}$ and other nutrients (folic acid, pyridoxine and magnesium) for conversion of tryptophan into serotonin ${ }^{2}$. In mourners, the replacement of nutrients and food components that have a beneficial influence on mental health needs to be implemented and with the combination of foods that provides the best response.

However, the treatment of patients with TC should be individualized according to their clinical, psychic and nutritional conditions. This requires the application of a more specific clinical-nutritional protocol, paying attention to diet and food components referenced as protectors of heart injury, as well as traumatic situations triggering this syndrome, seeking to identify the basis of each person's disturbances. If TC resulted from the loss of a loved one, cover the emotional stressors associated with this pecu- 
liarity, know the cause of death, the particularities of mourning, behavioural changes instituted after the death of the loved one, being aware of the changes that may have come up in sleep, diet, body weight and perimeter. Among the multiplicity of factors involved (psychic and physiological)in the genesis of the psychosomatic phenomenon, the situations of losses preceding the illness are more emphasized ${ }^{68}$, which redirects attention to the mourners because of their vulnerability to becoming ill. Considering the connection of emotional stress with the heart, depending on the psychic conditions of the bereaved, in addition to grief therapy ${ }^{20}$ and cardiac evaluation, it is reasonable to evaluate the need for pre-treatment with medication indication and referral to nutritional care, mainly in clinical cases of inability or refusal to eat. The way we deal with death and mourning has implications in eating behaviors, with serious consequences to health, ${ }^{2}$ and restoring, through food, benefits to the mind and heart, is realizing that, in the face of individuals destroyed by loss and with symptoms of anhedonia, nutritional management require gradual adaptation. Cases of stress-induced cardiomyopathy have been described in individuals with eating disorders, who reach higher severity because they are associated with prolongation of the QT interval due to electrolyte imbalances and hypoglycae$\mathrm{mia}^{69}$. It is conceived that cardiovascular research in mourners needs to be carried out, especially in the presence of well-defined behavioural and mood changes, and when severe diet restriction is noted.

\section{FINAL CONSIDERATIONS}

Deepening the psychic issues of mourning requires a careful look at individual differences in reaction to death. Mourning is not a process that progresses in a linear way, therefore, it deserves the deepening in studies that ally its effects to cardiac alterations.

In mourners, due attention to the cardiac symptoms of Takotsubo cardiomyopathy should also be part of the clinical care protocols, in order to guarantee more specific investigations directed to this syndrome. Because this cardiomyopathy has a strong association with emotional stress, greater attention in this recognition could contribute to the notification of clinical cases in Brazil.

The science of nutrition is inserted in this context because it favours, together with hemodynamic therapy and coping with mourning, not only benefits for the reestablishment of cardiac function, but also extends to diet planning applied to mental health and nutritional health.

\section{ACKNOWLEDGEMENTS}

To the cardiologists LPM (Hemodynamic Service, Hospital São João Batista, Viçosa, Minas Gerais, Brasil) and FMQV (Clinicor/Viçosa) for the provision of Figure 1.

\section{Conflict of Interest}

The authors declare no conflict of interest.

\section{RESUMO}

INTRODUÇÃo: Este artigo busca fazer referência a alguns aspectos do luto recente considerados fatores de risco para a doença cardiovascular, especificamente a cardiomiopatia de Takotsubo. Objetivou-se descrever o estresse proveniente da morte do ente querido aliando-o à possibilidade de ocorrência da cardiomiopatia de Takotsubo, mediante a percepção de um evento traumático pelo córtex que aciona o circuito cerebral subcortical tendo repercussões na resposta endócrina. Dado o crescente reconhecimento dessa cardiomiopatia, torna-se viável contextualizar as condutas nutricionais e as decisões que as norteiam, cujos benefícios devem ultrapassar a condição de disfunção cardíaca temporária e se estender às escolhas alimentares que exercem alguma influência no sistema límbico. Trata-se de uma análise descritiva que objetiva problematizar a temática em reflexões pautadas nessa vivência, considerando o alicerce com a ciência da nutrição.

PalaVRas-ChaVe: Cardiomiopatia de Takotsubo. Luto. Morte. Conduta nutricional.

\section{REFERENCES}

1. Sparrenberger F, Santos I, Lima RC. Epidemiology of psychological distress: a population-based cross-sectional study. Rev Saúde Pública. 2003;37(4):434-9.

2. Campos MT. The influence of mourning on feeding habits and its implications for nutritional behavior. Cien Saúde Colet. 2013;18(9):2769-79.

3. Varutti R, Setti T, Ezri T, Nicolosi G, Rellini G, Cassin M, et al. Postoperative Takotsubo cardiomyopathy triggered by intraoperative fluid overload and acute hypertensive crisis. Rom J Anaesth Int Care. 2015;22(1):47-50.
4. Sharkey SW, Lesser JR, Maron B). Cardiology patient page. Takotsubo (stress) cardiomyopathy. Circulation. 2011;124(18):e460-2.

5. Koulouris S, Pastromas S, Sakellariou D, Kratimenos T, Piperopoulos P, Manolis AS. Takotsubo cardiomyopathy: the "broken heart" syndrome. Hellenic J Cardiol. 2010;51(5):451-7.

6. Lemos AE, Araújo Junior AL, Lemos MT, Belém LS, Vasconcelos Filho FJ, Barros RB. Broken-heart syndrome (Takotsubo syndrome). Arq Bras Cardiol. 2008;90(1):e1-3. 
7. Ramírez Chaves ||, Calderón Calvo C. Miocardiopatía tipo Takotsubo. Rev Costarric Cardiol. 2014;16(1):25-32

8. Reis JGV, Rosas G. Cardiomiopatia de Takotsubo: um dignóstico diferencial da síndrome coronariana aguda: revisão da literatura. Rev Méd Minas Gerais 2010;20(4):594-600

9. Gómez AR, Herrera S, Ochoa |, Velásquez |G. Miocardiopatía por estrés: serie de casos. Rev Colomb Cardiol. 2015;22(2):97-101.

10. Cesário V, Loureiro M), Pereira H. Takotsubo cardiomyopathy in a cardiology department. Rev Port Cardiol. 2012;31(9):603-8.

11. Menezes $M N$, Silva $D$, Almeida $A G$, Pinto Fl, Brito $D$. A rare case of concomitant stress (Takotsubo) cardiomyopathy and acute myocardial infarction. Rev Port Cardiol. 2015;34(7-8):499.e1-3.

12. Okoshi K, Okoshi MP. Cardiomiopatia de Takotsubo. Rev Soc Cardiol 2009:19(1):87-92.

13. Rodrigues LB, Batista A, Monteiro F, Duarte IS. ST-segment elevation during general anesthesia for non-cardiac surgery: a case of Takotsubo. Rev Bras Anestesiol. 2015;65(5):403-6.

14. Amaral WAEF, Miranda Z, Miranda G, Ferreira WV, Gonçalves RPF, Silva PLN. Disfunção ventricular apical transitória (Síndrome de Takotsubo): uma revisão da literatura. Arq Catarin Med. 2014:43(4):70-6.

15. Hoekstra BE, Reis ESS, Ribeiro B, Costa MAC. Doença de Takotsubo (síndrome do coração partido): uma doença subdiagnosticada? Rev Bras Cardiol. 2014;27(5):327-32.

16. Chesney SA, Gordon NS. Profiles of emotion regulation: understanding regulatory patterns and the implications for posttraumatic stress. Cogn Emot. 2017:31(3):598-606

17. Stroebe M, Schut H, Stroebe W. Health outcomes of bereavement. Lancet. 2007;370(9603):1960-73.

18. Silva ACO, Nardi AE. Luto pela morte de um filho: utilização de um protocolo de terapia cognitivo-comportamental. Rev Psiquiatr Rio Gd Sul. 2010;32(3):113-6.

19. Mostofsky E, Maclure M, Sherwood IB, Tofler GH, Muller JE, Mittleman MA. Risk of acute myocardial infarction after the death of a significant person in one's life: the Determinants of Myocardial Infarction Onset Study. Circulation. 2012;125(3):491-6.

20. Batista JS, Mazorra L. Luto e doença cardíaca. Rev Soc Cardiol 2015;25(4):156-9.

21. Sénior IM, Artunduaga NT, Cadavid AF, Dimuro AR. Cardiomiopatia de Takotsubo. latreia. 2015;28(2):202-6.

22. Ribeiro VFA, Vasconcelos M, Melão F, Ferreira E, Malangatana G, Macie M). Desfecho de curto e longo prazo na cardiomiopatia induzida por estresse: o que podemos esperar? Arq Bras Cardiol. 2014;102(1):80-5.

23. Montera MW, Mesquita ET, Colafranceschi AS, Oliveira AC Jr, Rabis choffsky A, lanni BM, et al; Sociedade Brasileira de Cardiologia. I Brazilian guidelines on myocarditis and pericarditis. Arq Bras Cardiol. 2013;100(4 Suppl 1):1-36.

24. Battioni L, Costabel JP, Mondragón IL, Russo A, Villariño BS, Lamelas PM. Diferencias electrocardiográficas entre Takotsubo e infarto agudo de miocárdio. Rev Fed Arg Cardiol. 2015;44(1):51-4

25. Prasad A. The "broken heart syndrome": state of the art. Circulation. 2007;115(5):e56-9

26. Nóbrega S, Brito D. Miocardiopatia Takotsubo: estado da arte. Rev Port Cardiol. 2012;31(9):589-96.

27. Pitthan E, Martins OMO, Barbisan IN. Novos biomarcadores inflamatórios e de disfunção endotelial: predição de risco cardiovascular. Rev AMRIGS. 2014;58(1):69-77.

28. Jensen MK, Bertoia ML, Cahill LE, Agarwal I, Rimm EB, Mukamal KJ. Novel metabolic biomarkers of cardiovascular disease. Nat Rev Endocrinol. 2014;10(11):659-72

29. Hajjar LA, Fernandes Jr C), Mercon ES, Góis AFT, Knobel E, Kopel L et al. Disfunção miocárdica na sepse. Rev Bras Ter Intensiva. 2004;16(3):185-91.

30. von Haehling S, Genth-Zotz S, Bolger AP, Kalra PR, Kemp M, Adcock IM et al. Effect of noradrenaline and isoproterenol on lipopolysaccharide-induced tumour necrosis factor-alpha production in whole blood from patients with chronic heart failure and the role of beta-adrenergic receptors. Am | Cardiol. 2005;95(7):885-9.

31. Kawai S, Kitabatake A, Tomoike H; Takotsubo Cardiomyopathy Group. Guidelines for diagnosis of Takotsubo (ampulla) cardiomyopathy. Circ I. 2007;71(6):990-2.
32. Compare A, Proietti R, Del Forno D, Vitelli A, Grieco A, Maresca L, et al. Vulnerable personality and Takotsubo cardiomyopathy consequent to emotional stressful events: a clinical case report. Monaldi Arch Chest Dis. 2011;76(2):99-103.

33. Redfors B, Shao Y, Omerovic E. Stress-induced cardiomyopathy (Takotsubo): broken heart and mind? Vasc Health Risk Manag. 2013;9:149-54.

34. Graff S, Fenger-Gron M, Christensen B, Pedersen HS, Christensen J, Li J, et al. Long-term risk of atrial fibrillation after the death of a partner. Open Heart. 2016;3(1):e000367.

35. Gomes MF, Chowdhary N, Vousoura E, Verdeli H. "when grief breaks your heart": a case study of interpersonal psychotherapy delivered in a primary care setting. J Clin Psychol. 2016;72(8):807-17.

36. Crawford PA, Schaffer JE. Metabolic stress in the myocardium: adaptations of gene expression. J Mol Cell Cardiol. 2013;55:130-8.

37. Coupez E, Eschalier R, Pereira B, Pierrard R, Souteyrand G, Clerfond G, et al. A single pathophysiological pathway in Takotsubo cardiomyopathy: catecholaminergic stress. Arch Cardiovasc Dis. 2014;107(4):245-52.

38. Douglas CR. Controle da ingestão alimentar. In: Douglas CR, org. Tratado de fisiologia aplicada à nutrição. São Paulo: Robe Editorial; 2002. p.473-84.

39. Vale S. Psychosocial stress and cardiovascular diseases. Postgrad Med I. 2005;81(957):429-35.

40. Adameova A, Abdellatif $Y$, Dhalla NS. Role of the excessive amounts of circulating catecholamine and glucocorticoids in stress-induced heart disease. Can | Physiol Pharmacol. 2009;87(7):493-514.

41. Oliveira IS, Bressan I. Tecido adiposo como regulador da inflamação e da obesidade. EFDeportes.com Rev Digital. [serie na internet] 2010 nov. [acessado 19 Jun 2017]; ano 15, 150:[aprox.10]p. Disponível em: http:// www.efdeportes.com/efd150/tecido-adiposo-como-regulador-da-obesidade.htm

42. Almeida El, Garcia-Santos S, Haas El. Padrões especiais de luto em mães que perderam filhos por morte súbita. Rev Psicol IMED. 2011;3(2):607-16

43. Dietz LJ, Stoyak S, Melhem N, Porta G, Matthews KA, Walker Payne MI, et al. Cortisol response to social stress in parentally bereaved youth. Biol Psychiatry. 2013;73(4):379-87.

44. Norcliffe-Kaufmann L, Kaufmann H, Martinez I, Katz SD, Tully L, Reynolds HR. Autonomic findings in Takotsubo cardiomyopathy. Am J Cardiol. 2016;117(2):206-13

45. Ried K, Fakler P. Potential of garlic (Allium sativum) in lowering high blood pressure: mechanisms of action and clinical relevance. Integr Blood Press Control. 2014;7:71-82.

46. Suleria HA, Butt MS, Anjum FM, Saeed F, Khalid N. Onion: nature protection against physiological threats. Crit Rev Food Sci Nutr. 2015;55(1):5066.

47. Zhang $H$, Tsao R. Dietary polyphenols, oxidative stress and antioxidant and anti-inflammatory effects. Curr Opin Food Sci. 2016;8:33-42.

48. Campos MTFS, Coelho AIM. Alimentação saudável na terceira idade: estratégias úteis. 3a ed. Viçosa: Editora UFV; 2013. p.55-100.

49. Angelo PM, Jorge N. Compostos fenólicos em alimentos: uma breve revisão. Rev Inst Adolfo Lutz. 2007;66(1):1-9.

50. Costa $T$, lorge N. Compostos bioativos benéficos presentes em castanhas e nozes. UNOPAR Cient Ciênc Biol Saúde. 2011;13(3):195-203.

51. Marion M, Carvalho IAM, Bochi GV, Sangoi MB, Moresco RN. Ácido úrico como fator de risco para doenças cardiovasculares e síndrome metabólica. Rev Bras Farm. 2011;92(1):3-8.

52. Gabriel EA, Almeida APF, Saraiva JFK. Hiperuricemia como fator de risco cardiovascular. Rev Ciênc Méd. 2001;10(2): 43-6.

53. Oliveira A, Miranda Hermsdorff HH, Guedes Cocate P, Bressan |, Azevedo Novello A, Cardoso dos Santos E, et al. The impact of serum uric acid on the diagnostic of metabolic syndrome in apparently healthy Brazilian middle-aged men. Nutr Hosp. 2014;30(3):562-9.

54. Silva HA, Carraro IC, Bressan |, Hermsdorff HH. Relation between uric acid and metabolic syndrome in subjects with cardiometabolic risk. Einstein (São Paulo). 2015;13(2):202-8.

55. Rizkalla SW. Health implications of fructose consumption: a review of recent data. Nutr Metab (Lond). 2010;7:82.

56. Lustig RH. Fructose: It's "alcohol without the buzz". Adv Nutr. 2013;4(2):226-35

57. Silva BYC, Martins TF. Alimentos prebióticos e probióticos na manutenção da saúde humana: qual a abrangência? Rev Aten Saúde. 2015;13(44):71-9. 
58. Gusmão LS, Sperandio N, Morais DC, Dutra LV, Pinto CA, Priore SE. Utilização de indicadores dietéticos como critérios prognósticos da síndrome metabólica. RASBRAN. 2014;6(1):37-46.

59. Cryan JF. Stress and the microbiota-gut-brain axis: an evolving concept in psychiatry. Can | Psychiatry. 2016;61(4):201-3.

60. Bercik P, Collins SM, Verdu EF. Microbes and the gut-brain axis. Neurogastroenterol Motil. 2012;24(5):405-13.

61. Santos RD, Gagliardi ACM, Xavier HT, Magnoni CD, Cassani R, Lottenberg AM, et al; Sociedade Brasileira de Cardiologia. First guidelines on fat consumption and cardiovascular health. Arq Bras Cardiol. 2013;100(1 Suppl 3):1-40.

62. National Academy of Sciences. Institute of Medicine. Food and Nutrition Board. Dietary reference intakes for energy, carbohydrate, fiber, fat, fatty acids, cholesterol, protein, and amino acids (macronutrients). 2005. [cited 2018 Jan 3] Available from: https://www.nap.edu/read/10490/chapter/1

63. Barbosa JH, Oliveira SL, Seara LT. The role of advanced glycation end-products (AGEs) in the development of vascular diabetic complications. Arq Bras Endocrinol Metabol. 2008;52(6):940-50.

64. Uribarri J, He JC. The low AGE diet: a neglected aspect of clinical nephrology practice? Nephron. 2015;130(1):48-53.

65. Shibao J, Bastos DHM. Produtos da reação de Maillard em alimentos: implicações para a saúde. Rev Nutr. 2011;24(6):895-904.

66. Scherr C, Ribeiro JP. Composição química de alimentos: implicações na prevenção da aterosclerose. Rev Assoc Med Bras. 2011;57(2):153-7.

67. Esperidião-Antônio V, Majeski-Colombo M, Toledo-Monteverde D, Moraes-Martins G, Fernandes JJ, Assis MB, et al. Neurobiologia das emoções. Rev Psiquiatr Clín. 2008;35(2):55-65.

68. Bandeira MF, Barbieri V. Personalidade e câncer de mama e do aparelho digestório. Psic Teor e Pesq. 2007;3(3): 295-304.

69. Vadalá S, Pellegrini D, Verdaguer MF, Schrappe M, Alvarez J, Bruetman E. Stress (Takotsubo) cardiomyopathy in a patient with anorexia nervosa. Medicina (B Aires). 2014;74(3):222-4. 